Encounters on Education

Volume 7, Fall 2006 pp. 1 - 3

\title{
Introduction
}

\section{Education and social processes: An historical approach}

\section{Rosa Bruno-Jofré and Gonzalo Jover Olmeda}

Queen's University and Universidad Complutense de Madrid

$\mathrm{I}_{\mathrm{n}}^{\mathrm{s}}$ N THIS SEVENTH ISSUE OF Encounters/Encuentros/Rencontres we include the usual thematic collection of articles, but we also inaugurate an open section to be able to provide an avenue for authors who submit papers that are not related to the central theme. Another innovation is the Special Feature section that in future issues may include unique archival documents and related discussion, oral narratives from historical protagonists, methodological reflections, reflective essays, or a even a multimedia production that would be included in the Web publication of Encounters.

Given the nature of the theme of this issue, we invited Daniel Tröhler to lead the collection with a historiographical analysis that would address the question: How can historical knowledge inform educational theory and practice? Tröhler turns to the philosophy of language distinctions between paroles and langues as a methodological tool to bridge the traditional dichotomy of traditional history of ideas and social history. Tröhler's article probes deeply and widely in search of the old roots of contemporary school issues. This paper embodies serious matters of interest to historians of education.

The thematic papers in this issue reflect contemporary developments in the history of education, as is evident in foci on the early traveling of ideas, the convergence of political and educational projects, and the relationship between gender and power. Thus, Part I, Gendering history of education includes two articles. Elizabeth Smyth's "Loretto Academy Niagara (1861-1969): Education under the rainbow" is an innovative history in which the natural environment along with the school's physical development, and the gendered environment converge to explain the overt and hidden curriculum of the Academy. Teresa Rabazas Romero and Sara Ramos Zamora's "La construcción del género en el franquismo y los discursos educativos de la Sección Femenina" (The construction of gender under the Franco Regime in Spain and the educational discourse of the Feminine Section), analyses the changes in the educational 
discourse of the Franco regime and the changing components of the discourse as the regime demands new political and economic adaptations. They situate it as a cultural history. The authors trace the discourse of the Sección Femenina, one of the organizations working with the regime, through the examination of Consigna, the magazine that was the vehicle for indoctrinating the values expounded by the regime and propounding a normalizing notion of womanhood used by the party. It was addressed to women, but was expected to reach, in particular, elementary teachers.

Part II, includes three articles that show a strong historiographical movement toward the understanding of international connectedness in educational developments: the first is Paulí Dávila Balsera and Luis María Naya Garmendia’s "La evolución de los derechos de la infancia: Una visión international" (The evolution of children's rights: an international vision) brings a refreshing new perspective. On one side, the authors examine the historical processes leading to the national and international acknowledgement of the child as a human being with rights and the changes in the legal approach that led to the understanding of the child as a subject of rights rather than an object of rights. On the other side, the authors introduce the readers to a discourse analysis of children's rights as expounded in international agreements. They argue that the emphasis has been on the need for protection and provision of basic needs, and on autonomy rights. The latter makes children legal subjects with a preoccupation for children who are socially excluded or in vulnerable situations.

Julio Ruiz Berrio’s "Las reformas históricas de la enseñanza secundaria en España" (The historical reforms of secondary education in Spain) critically situates the changes in secondary education in Spain in a solid European historical framework. The author takes a "long durée" historical approach to analyse the changes in a contextualized manner while rescuing the language of the classroom and the culture of the secondary schools. He argues that in many cases the new plans gave priority to instruction over education.

Bruce Curtis' "Tocqueville and Lower Canadian educational networks" takes the reader to a fascinating journey away from conventional historiography. He examines how educational projects were political projects as part of the attempt to build a cultivated polity. Curtis argues that the understanding of basing the rule on the disciplined will was at the forefront in the 1830s. The analysis of the interactions with Tocqueville in Lower Canada and the connections with the other side of the Atlantic makes this paper unique.

The new Open Section has an article by Carolina Fernández-Salinero Miguel entitled "Las Competencias en el marco de la convergencia europea: Un nuevo concepto para el diseño de programas educativos" (Competencies within the framework of the European convergence: A new concept used in the design of educational programs). The author places the development of the concept within the creation of the European higher education space and the many agreements and initiatives that generated legitimized meanings of the concept. She provides a very useful general framework for the design of programs based on competencies, but invites the readers not to lose sight 
of two complementary goals: first, quality education for all, and second, the integration of educational activities with developments in science, technology, and the pursuit of knowledge.

The Special feature of this issue: Creating through historical engagement and process: the inner voice of an artist presents an essay by Alfred Fisher entitled "Protecting history, resisting legibility: Voice and defiance in making art." This piece challenges the reader to pause and engage with the text, written by a music composer, in a multifaceted and dynamic way. Scott Johnston, a philosopher of education, wrote an interpretative response that is followed by Alfred Fisher's reaction. 
4 Encounters/Encuentros/Rencontres 